\title{
Recent Trend in Environmental Regulation Level for Energy Plants Using Solid Fuels
}

\author{
Yongseung Yun*
}

Vice President, Institute for Advanced Engineering, Republic of Korea

ISSN: 2578-0255

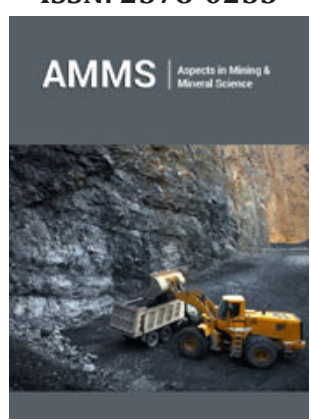

*Corresponding author: Yongseung Yun, Vice President, Institute for Advanced Engineering, Yongin, Gyunggi-do, Republic of Korea

Submission: 酸 September 14, 2019

Published: 制September 25, 2019

Volume 3 - Issue 5

How to cite this article: Yongseung Yun Recent Trend in Environmental Regulation Level for Energy Plants Using Solid Fuels. Aspects Min Miner Sci.3(5). AMMS.000571.2019.

DOI: 10.31031/AMMS.2019.03.000571

Copyright@ Yongseung Yun, This article is distributed under the terms of the Creative Commons Attribution 4.0 International License, which permits unrestricted use and redistribution provided that the original author and source are credited.

\begin{abstract}
Key words for the future energy direction must be clean, $\mathrm{CO}_{2}$-free, renewable, and sustainable. Since solid fuels are still abundant and relatively cheap, it is inevitable to use solid fuels as an interim medium until energy plants can meet the future technological demand. Solid fuels are targets of scaling down in many countries by environmental issues of fine particulate or dioxin, etc. There are several Korean cases that are worthy of discussion in terms of environmental performance using solid fuels compared to the legal emission standards, and related NIMBY issues. Future direction clearly indicates that any energy plants using solid fuels should prepare to the emission level of large-scale coal-fired power plants and to the ever-increasing NIMBY case. It necessitates early adaptation to the related best available technologies as well as the in-depth study on possible options such as underground installation with near pollution-free configuration
\end{abstract}

Keywords: Energy plant; Solid fuel; Emission level; NIMBY

Abbreviations: NIMBY: Not-In-My-Back-Yard; NG: Natural Gas; SRF: Solid Refuse Fuel; BAT: Best-Available-Technology

\section{Introduction}

Recent trend on energy utilization can be summarized with key words like climate change, $\mathrm{CO}_{2}$-free, renewable, and extreme minimization of pollutants. All these key words have caused dramatic transformation in energy field, especially in solid fuel utilization area. The future primary energy source requires characteristics of $\mathrm{CO}_{2}$-free and pollution-free, which are not practical for a while except a few areas of the world. There are many progresses in renewable $\mathrm{CO}_{2}$-free electricity that comes from wind turbines and solar panels, and green hydrogen has emerged as an ultimate $\mathrm{CO}_{2}$-free electricity to be sought for. But there are not yet reliable and affordable technologies available in accomplishing the goal. From the viewpoint of hydrogen, hydrogen that made from solid fuels is classified as gray hydrogen since some $\mathrm{CO}_{2}$ is accompanied during the production process, whereas the green hydrogen that made through wind/solar renewable energy sources has a feature of minimal or no $\mathrm{CO}_{2}$ production. Transition from the gray hydrogen to green hydrogen society is not an easy and cheap task and necessitates the transition period of using the clean technologies that can minimize pollutants and $\mathrm{CO}_{2}$ emissions. Inevitable utilization of solid fuels for energy generation until the era of green energy society conflicts with the future direction that wants to be $\mathrm{CO}_{2}$-free and pollution-free.

There have been several possible routes for the reliable and clean future energy supply. Among them, renewable energy, hydrogen energy, natural gas (NG) including shale gas, ultra-low sulfur liquid fuels are most prominent choices. Solid fuels like coal, pet-coke, waste fuels are key targets that should be eliminated in the next few decades by environmental groups and by some politicians. As well known, solid fuel usage in energy plants has severely influenced by environmental issues such as the response to climate change, ultimate reduction of environmental pollutants, and removing fine/ultrafine particulates, etc. These issues proceed to the direction that minimizes the use of solid fuels or eventual ban as energy supply sources, resulting that new energy-plant construction itself becomes almost impossible in many countries. In most cases, the technological development that has reached during the last decade with respect to pollutant control and to $\mathrm{CO}_{2}$ minimizing techniques is unfortunately often disregarded. In many countries and states, solid fuel itself has banned inside cities. In Korean case, it's been enforced in Seoul and in major key cities from 1985 for the purpose of reducing air pollution that was severe in that era by heavy use of coal briquette for heating. From 1988, 
only clean fuels (LNG, LPG) were allowed for boilers, co-generation, and power plants in areas that exhibit heavy air pollution [1]. In Korea, during the last decade, the number of days showing low visibility by fine particulates increased dramatically, which prompts to actions related to solid fuels by central/local government. New installation of coal-fired power plant has halted, and old coal power plants of more than 30 years age are in the process of dismantling. This kind of coal bashing is widespread worldwide. Recent related case can be seen in the March 2019 decision by Polish supreme court [2] in that solid coal and wood burning is banned at Krakow. Krakow and the surrounding Malopolska region has been known as one of the most polluted regions in the EU, especially for particulate matter $\left(\mathrm{PM}_{10}\right)$. The target is to eliminate the dust from domestic boilers using solid fuels.

Overall regulation level on air pollution gets stringent more than ever, especially from the year after 2000 . With high stringent rate in allowed pollutants concentrations, residents loathe intensely any energy-related plants, sometimes even for the NG power plants and renewable facilities like fuel cells using hydrogen [3]. The current situation related to the energy plants using solid fuels is discussed with central focus on Korean experience. Here, solid fuels mean coal, pet-coke, and solid refuse fuel (SRF) made from municipal solid wastes.

\section{Comparison of Legal Environmental Regulation Level with Actual Implementation in Korea}

Table 1 shows the environmental permit values for energy plants as well as the values in actual plant cases in Korea. As a reference value to the energy plants using solid fuels, permit values for NG energy plants are also shown. NG has regarded as a typical clean fuel which does not initiate much conflict in permitting and construction steps. Most practical environmental target for energy plants resides in the permitting level of NG plants. If the energy plants using solid fuels can meet even the lower environmental emission level than the NG energy plant, solid fuels should not be eliminated by the reason of environmental emission. However, it is not the case in many places. Solid fuels contain various heavy metals, chloride, and mercury although concentrations remain in the ppm level. One important point here is that most of latest energy plants using solid fuels operate with pre-treatment process before injecting the solid fuels into the furnace or reactor, in order to minimize these harmful ingredients. Even with pre-treatment, definitely a small portion of harmful ingredients will end up in flue gas or in ash from the high temperature facility, but the latest pollution control system can handle within the environmental regulation level. Two cases are shown in Table 1. First one is the cogeneration energy project using SRF/NG at Naepo new city in Korea. Total planned project cost was US $\$ 450$ million for the plant that was initiated in 2010 and planned to produce 97MW electricity and 394.4Gcal/hr heat for servicing 100,000 people [4]. Environmental group and nearby residents raised the issue of environmental harmfulness by using SRF which, they insist, is basically identical with municipal solid wastes, and asked to co-generate only with NG. The plant started to construct in 2016, and after 2017 it was halted. The private consortium for the project proposed in 2017 to build the plant that can satisfy even lower than the NG standard to the level of SOx 8pm, NOx 20ppm, dust 3ppm, and dioxin 0.01ng (Table 1). But, with objection by nearby residents who ask to use only NG, the project is still being delayed.

Table 1: Comparison of environmental permit values for different energy plants with actual plant cases in Korea [3,4].

\begin{tabular}{|c|c|c|c|c|c|c|c|c|}
\hline \multirow{3}{*}{ Item } & \multicolumn{6}{|c|}{ Korean Legal Environmental Permit Values } & \multirow{3}{*}{$\begin{array}{l}\text { Special Permit } \\
\text { Limit for } \\
\text { Naepo new } \\
\text { city (SRF + LNG } \\
\text { cogeneration) }\end{array}$} & \multirow{3}{*}{$\begin{array}{c}\text { Najoo SRF } \\
\text { Power Plant } \\
\text { (design } \\
\text { values) }\end{array}$} \\
\hline & \multicolumn{3}{|c|}{ LNG Power Plant } & \multirow{2}{*}{$\begin{array}{c}\text { Large MSW } \\
\text { Incinerator } \\
\text { (Energy Recovery } \\
\text { Plant) }\end{array}$} & \multicolumn{2}{|c|}{ SRF Power Plant } & & \\
\hline & $\begin{array}{l}\text { Operational } \\
\text { Before } 2015\end{array}$ & $\begin{array}{l}\text { New Permit } \\
\text { From } 2015\end{array}$ & $\begin{array}{l}\text { New Permit } \\
\text { From } 2020\end{array}$ & & Current & $\begin{array}{c}\text { New Permit } \\
\text { From } 2020\end{array}$ & & \\
\hline $\mathrm{SO}_{\mathrm{X}}(\mathrm{ppm})$ & 35 & 20 & 10 & 30 & 30 & 20 & 8 & 10 \\
\hline $\mathrm{NO}_{\mathrm{X}}(\mathrm{ppm})$ & 50 & 20 & 10 & 70 & 70 & 50 & 20 & 25 \\
\hline $\begin{array}{c}\text { Dust (mg/ } \\
\mathrm{Nm}^{3} \text { ) }\end{array}$ & 15 & 10 & 10 & 20 & 20 & 10 & 3 & 5 \\
\hline CO (ppm) & 50 & 50 & 50 & 50 & 50 & 50 & 30 & 40 \\
\hline $\begin{array}{l}\text { Dioxin (ng- } \\
\text { TEQ/Sm }{ }^{3} \text { ) }\end{array}$ & - & - & - & 0.1 & 0.1 & 0.1 & 0.01 & 0.05 \\
\hline
\end{tabular}

Korea imports NG as a liquified form and thus NG is expensive, typically above US\$10/MMBtu. For simple price comparison only with calculation based on the fuel price per heating value, liquified NG was 3.66-4.12 times expensive than SRF as a fuel in Korea as of 2017 fall season. Project only with NG must accompany the electricity/heat price increase to end-users, but nobody was going to pay for it. Health threat by dioxin has been a favorite item that environmental citizens group insisted to protest the waste-related thermal plants, and the same protest had occurred in Naepo project.
Technically, the general scheme in dioxin generation/re-generation has been identified well enough, so as to enforce lawmakers to legalize the strict operating condition in waste incinerators and thermal plants: maintain minimum $2 \mathrm{sec}$ residence time in the second combustion section, keep the exit temperature of flue gas at the reactor outlet above $850{ }^{\circ} \mathrm{C}$, and the specific temperature conditions in the pollution control devices on the flue gas. It is all for the safe thermal destruction of dioxin. Since the dioxin is an organic compound, high temperature can destroy the chemical structure 
to be un-harmful gas compounds. Moreover chloride-containing plastics like PVC are pre-sorted and the quick quenching for flue gas has applied to prevent dioxin re-generation at around $300^{\circ} \mathrm{C}(250$ $450{ }^{\circ} \mathrm{C}$ ) by de-novo synthesis. Latest waste incinerators typically produce less than $0.01 \mathrm{ng}$ level of dioxin. With proper investment and maintenance, dioxin can be dealt with to be far lower values below the regulation level. Second case is the co-generation energy plant using SRF that had built the complete facilities and finished even the successful initial operation. Korea District Heat Co. which is a public enterprise invested US\$225 million to the Najoo new city co-generation plant that uses 466 ton-SRF/day to produce $21.99 \mathrm{MW}$ electricity and $45 \mathrm{Gcal} / \mathrm{hr}$ heat. The plant also includes two LNG-only heat supply boilers of 68Gcal/hr capacity each, which has operated from December 2015. The Najoo energy plant started the construction in 2014 and finished in December 2017 [5]. As shown in Table 1, Najoo plant was built based on the design values for pollutants in flues gas as SOx 10ppm, NOx 25ppm, dust $5 \mathrm{ppm}$, and dioxin $0.05 \mathrm{ng}$, which are well below the environmental permit values. But, the issue of using large volume of SRF originated from another city halted the commercial operation till now. Citizen groups insist that SRF should be replaced with NG because of the concerns on environmental pollutions as the plant scale of supplying just enough the city, and also that only SRF made from Najoo-originated solid wastes should be utilized if the SRF has ever to be used.

In the case of coal-fired power plants in Korea, measured airpollutant emission values in Table 2 demonstrated the much lower numbers than the legally allowed emission standards. USC(UltraSupercritical) coal-fired power plant of 1,000MW scale was built in Korea from 2016, and the 300MW-class IGCC (Integrated Gasification Combined Cycle) coal-fired power plant has commercially operated from 2017. Newly installed USC and IGCC coal-fired power plants exhibited improved environmental performance. In particular, IGCC power plant shows cleaner performance in emissions than even the NG-fired power plant. The coal IGCC power plant shows almost no emissions in SOx/dust and much lower NOx emission. When the IGCC coal power plant equips the SCR (selective catalytic reduction), which is widely used technology in NOx reduction, NOx emission can be lowered below 10ppm (probably around 5-7ppm). These emission values are even lower than the new lower regulation emission level on the NG-fired power plant that is scheduled to apply from 2020. These Korean experience in coal-fired power plants succinctly reveals that coal can work as cleanly as NG when the suitable technologies are implemented. But, coal IGCC power plant needs to reduce the investment cost from the current price tag of more than twice expensive than the conventional coal power plant. Recent trend clearly indicates that the energy plants using solid fuels should implement the newly available technologies, especially regarding the emission reduction, although the total cost surpasses the conventional case. In this respect, waste-based energy plants, which are typically in the range of 50-500ton/ day size, should prepare for the time when the environmental regulation level drops to the level of coal-fired power plants using the best-available-technology whose typical size is bigger than 2,500 ton/day.

Table 2: Emission values from existing coal-fired power plants in Korea (April 2017) [3].

\begin{tabular}{|c|c|c|c|c|c|}
\hline \multirow[t]{2}{*}{ Item } & \multicolumn{2}{|c|}{$\begin{array}{l}\text { Korean Legal Environmental Permit Values } \\
\qquad(>100 \mathrm{MW})\end{array}$} & \multirow{2}{*}{$\begin{array}{c}\text { Existing Coal fired } \\
\text { Power Plant (500 } \\
\text { MW-class) }\end{array}$} & \multirow{2}{*}{$\begin{array}{l}\text { Newly Installed USC } \\
\text { Coal Power Plant } \\
\text { (1,000 MW-class) }\end{array}$} & \multirow{2}{*}{$\begin{array}{c}\text { Newly Installed IGCC } \\
\text { Coal Power Plant } \\
\text { (300 MW-class) }\end{array}$} \\
\hline & New Plant & Old Plant & & & \\
\hline $\mathrm{SO}_{\mathrm{X}}(\mathrm{ppm})$ & 50 & $80-100$ & $13-36$ & 34 & 1 \\
\hline $\mathrm{NO}_{\mathrm{X}}(\mathrm{ppm})$ & 50 & $70-90$ & $41-67$ & 34 & $28^{*}(<10)$ \\
\hline Dust $\left(\mathrm{mg} / \mathrm{Nm}^{3}\right)$ & 10 & $20-25$ & $0-5$ & 1 & 0 \\
\hline
\end{tabular}

*: plans to install SCR for reducing NOx to $<10 \mathrm{ppm}$.

\section{NIMBY on Energy Plants Using Solid Fuels}

People's opposition to the energy plants using solid fuels is getting worse in city areas. Basically, due to the identical energy unit price for the electricity and heating inside the country or in state, people do not have any incentive in accepting any plants that will exist nearby with even a slim possibility of any emissions. Supplying through the small energy plants of distributed nature that can supply the just-needed energy to the user directly or charging a different price according to the distance from the emission source, might be solutions, but not practical solutions yet. Therefore NIMBY (Not-In-My-Back-Yard) continues. In the case of coal, most OECD countries try to scale down the portion of coal as energy source. Nearby citizens oppose the coal related plants if there are no compensation through incentives. In case of pet-coke, one Korean petroleum company failed to get the permit in 2019 for the new circulating fluidized combustion (CFBC) boiler facilities using pet-coke that was produced from its own plant and was supposed to replace the existing boiler facility using heavy oil. Since nearby companies in the industrial complex that is sharing various feedstock produce process steam by heavy oil, synergistic effort of steam generation by cheap pet-coke was obvious. But, due to the raised concern on fine particulates by nearby citizens [6], local and central government did not issue the permit. There are many latest fine particulate capturing technologies such as ceramic/metal filters or high temperature bag filters, etc. Scientific evaluation procedures that can persuade the ordinary citizen are in great need. Some people insist that any solid fuels derived from wastes cannot qualify as clean pro-environmental fuel. They argue that only gaseous fuels of LNG and LPG which are almost pollutionfree can be classified as clean fuels, as specified in Korean related law [7]. Focal point of insistence is that there cannot exist any proenvironmental waste energy when solid waste is involved. 


\section{Future Prospect}

Key words for the future energy direction must be clean, $\mathrm{CO}_{2}$ free, renewable, and sustainable. Unfortunately, however, the affordable technologies in fulfilling these goals are not ready yet. It might still take few more decades to attain. Since solid fuels are still abundant and relatively cheap, it is inevitable to use solid fuels as an interim medium for energy plants in such a way that BAT (BestAvailable-Technology) should be implemented to make near $\mathrm{CO}_{2}-$ free and near pollution-free as much as possible. There are several good examples demonstrating that this is possible, like a coal IGCC power plant in the case of coal. Without any consensus regarding the high cost burden and technology-readiness during the process going into the future energy direction, conflict between the interim use of solid fuels and the wish for truly clean energy surely continues while increasing social cost. Starting point in relieving the severity of the conflict may reside in disseminating and sharing the information that both the ordinary citizen as well as technical experts can agree. Long-term operation data in the energy plant that shows world best performance for pollutants including dioxin may be a good example. There circulates too many unscientific and non-technical information for energy plants using solid fuels.

Almost all new projects related to solid wastes are in suspended state in the current Korean situation. It is worth to mention that the most profitable business model with respect to solid fuels in Korea has been the industrial steam production business that utilizes RFP(Refuse Plastic Fuel) in the rotating-type incineration reactor, and that utilizes pet-coke in circulating fluidized-bed combustion boilers. This business model requires conditions that there should be nearby large volume steam users, and the location be in the industrial complex where legal permit is available with no NIMBY possibility. The business has known unofficially to yield the payback period for invested capitals as 1.5-2 years. To widely use solid fuels such as coal, pet-coke, refuse solid fuels for the energy plants, several social demand should be met such that proper BAT should be implemented for fulfilling ever-stringent environmental regulations as well as the innovative response to ever-increasing NIMBY. There should be a model case in that inevitably increasing cost through the $\mathrm{CO}_{2}$-free and pollution-free process is shared for each stakeholder for minimal related social cost, and it should be shared as a public information. Another important area should be installing the energy plants in city areas under the ground in full or in half. Definitely the construction cost increases at least 1.5 times, typically around 2.5 times than the open green field construction. But, if there exists a severe opposition or possesses a confined space, it is a worthy option of consideration. Few examples already exist: the half-underground municipal solid waste incineration plant in Paris, and the full-underground waste treatment complex in Hanam city in Korea. Hanam facility composes of 48ton/day incinerator, 32,000ton/day wastewater treatment system, and 80 ton/day waste food treatment system.

\section{References}

1. Kang MO (2003) Study on remedial policy for solid fuel use restriction. Technical Report by Korea Environment Institute, Korea.

2. https://www.clientearth.org/polands-top-court-upholds-solid-fuelban-for-krakow/

3. Yun Y (2018) Economical/Environmental Characteristics and Public Acceptance for SRF Co-generation, Proceedings of Korea Association of Waste-to-Energy 2018 Spring Technology Workshop.

4. Naepo Green Energy Co., Brochure for Public Hearing on Community Energy Project of Naepo New City.

5. https://www.sisajournal.com/news/articleView.html?idxno=179993 (in Korean).

6. http://www.sstimes.kr/news/articleView.html?idxno=11401(in Korean).

7. Korean Air Environmental Conservation Act, Clause 43.

For possible submissions Click below: 